Analitika: Jurnal Magister Psikologi UMA, Vol. 12 (1) Juni (2020)

ISSN: 2085-6601 (Print), ISSN: 2502-4590 (Online)

DOI: http://dx.doi.org/analitika.v11i1.3110

ANALITIKA

Jurnal Magister Psikologi UMA

Available online http://ojs.uma.ac.id/index.php/analitika

\title{
Kecemasan dan Prestasi Akademik pada Mahasiswa
}

\section{Anxiety and Academic Achievement in College Students}

\author{
Dhian Kusumastuti* \\ Program Magister Psikologi Profesi, Fakultas Psikologi, Universitas Airlangga, Indonesia
}

Diterima: 24 November 2019, disetujui: 11 Juni 2020, dipublish: 30 Juni 2020

*Corresponding author: Email: dhian.kusumastuti-2019@psikologi.unair.ac.id

\begin{abstract}
Abstrak
Mahasiswa dalam masa pendidikannya kerap mengalami hambatan yang berdampak pada rendahnya prestasi akademik yang mereka capai. Salah satu hambatan yang mereka hadapi adalah masalah kecemasan. Kecemasan adalah perasaan subjektif dari ketegangan, ketakutan, kegugupan, dan kekhawatiran yang terkait dengan peningkatan aktivitas sistem saraf. Penelitian ini merupakan penelitian dengan tinjauan sistematik terhadap 5 literatur yang meneliti mengenai kecemasan dengan prestasi akademik. Literatur pada penelitian ini diperoleh melalui basis pencarian data science direct, ProQuest dan Education Research Information Center. Kata kunci yang digunakan dalam pencarian jurnal adalah "anxiety" and "academic achievement" and ("college student" or "university student"). Penelitian ini bertujuan ini mengetahui gambaran umum mengenai kecemasan mahasiswa dan hubungannya dengan prestasi akademik mereka. Hasil dari penelitian ini menunjukkan bahwa tinggi nya tingkat kecemasan diikuti oleh rendahnya prestasi akademik para mahasiswa. Hal ini berarti kecemasan memiliki hubungan negatif yang signifikan terhadap prestasi akademik mahasiswa. Terdapat berbagai jenis kecemasan yang bisa dialami oleh mahasiswa. Perbedaan ini dapat disebabkan oleh perbedaan ciri khas pada ruang lingkup pendidikan yang mereka tempuh.
\end{abstract}

Kata kunci: Kecemasan; Mahasiswa; Prestasi Akademik

\begin{abstract}
Students in their education often experience obstacles that have an impact on the low academic. One of the obstacle they face is the problem of anxiety. Anxiety is a subjective feeling of tension, fear, nervousness, and anxiety associated with the arousal of the nervous. This research is a systematic review that examines 5 literature about the relationship between anxiety and academic achievement. Literature in this study was obtained through some databases such as science direct, ProQuest, and Education Research Information Center. Keywords that were used in this study were "anxiety" AND "academic achievement" AND ("college student" OR "university student"). This study aims to describe student anxiety and its relationship with their academic achievement. The results of this study indicate that high levels of anxiety are followed by low academic achievement of students. This means that anxiety has a significant negative relationship on student academic achievement. Various types of anxiety that can be experienced by students. These differences can be caused by differences in the characteristics of the scope of education they are in.
\end{abstract}

Keywords: Academic Achievement; Anxiety; College Student

How to Cite: Kusumastuti, D. (2020). Kecemasan dan Prestasi Akademik pada Mahasiswa. Analitika: Jurnal Magister Psikologi UMA, 12 (1): 22 - 33 


\section{PENDAHULUAN}

Seiring dengan perkembangan zaman, pendidikan menjadi sebuah hal yang semakin penting untuk diperhatikan. Individu yang berkualitas diciptakan melalui peran penting pendidikan (Azizy, I. V., Mustikawati, I. F., \& Ulfa, 2019). Semakin tinggi tingkat pendidikan seseorang semakin baik pula kualitas orang tersebut. Keberhasilan individu juga kerap didasarkan pada kesuksesan selama berada di bangku perguruan tinggi. Pada budaya barat saat ini, cara penting untuk dapat mencapai kemakmuran dan kesejahteraan adalah melalui kesuksesan di perguruan tinggi (Brook, C., \& Wiloughby, 2015).

Kesuksesan di dalam ruang lingkup pendidikan kerap kali dikaitkan dengan prestasi akademik yang berhasil dicapai. Prestasi akademik adalah kriteria yang digunakan untuk menilai kesuksesan mahasiswa dalam proses pendidikan mereka, sehingga penting untuk memahami faktor yang berpengaruh, memprediksi, memediasi atau menyebabkan variasi prestasi akademik (Ahmad \& Bruinsma dalam Khalaila, 2014). Cara yang dapat digunakan untuk melihat prestasi akademik seorang mahasiswa salah satu nya adalah melalui tes dan ujian. Tes dan ujian di semua tahap pendidikan, terutama di tingkat pendidikan tinggi telah dianggap sebagai alat penting dan kuat untuk pengambilan keputusan dalam masyarakat kompetitif kita (Rana, R. A., \& Mahmood, 2010).

Pada kenyataannya, tidak semua mahasiswa dapat mencapai prestasi akademik yang baik. Berdasarkan data dari beberapa universitas didapatkan data bahwa beberapa mahasiswa memiki prestasi yang kurang baik. Penelitianpenelitian terdahulu (Azizy, dkk, 2019; Vitasari, dkk, 2010; Wahyudi, 2015) membuktikan bahwa banyak mahasiswa yang memiliki prestasi akademik yang kurang baik.

$\begin{array}{ccc}\text { Pada } & \begin{array}{c}\text { beberapa } \\ \text { psikologis }\end{array} & \begin{aligned} \text { literatur } \\ \text { berpendapat }\end{aligned}\end{array}$
perbedaan dalam pemrosesan kognitif tidak cukup untuk menjelaskan perbedaan dalam capaian prestasi akademik(Thomas, C., Cassady, J., \& Heller, 2017). Terdapat beberapa faktor lain yang berhubungan dengan capaian prestasi akademik salah satunya adalah tingkat kecemasan mahasiswa. Berdasarkan beberapa penelitian terdahulu telah terbukti bahwa kecemasan memiliki hubungan dengan pencapaian prestasi akademik. Berdasarkan peneitian yang dilakukan oleh Marthoenis, dkk. (2018) didapatkan data bahwa kecemasan merupakan hal yang kerap terjadi di kalangan mahasiswa dengan taraf antara 15\% sampai dengan 64,3\% mahasiswa dalam sebuah universitas. Pendapat serupa dikemukakan oleh McCraty (2007) bahwa kecemasan saat belajar adalah prediktor utama kinerja akademik. Sementara menurut Tobias dalam Vitasari, dkk. (2010) juga mengatakan bahwa kecemasan memiliki peran penting dalam pembelajaran siswa dan kinerja akademik serta memiliki efek memfasilitasi dan melemahkan prestasi akademik.

Kecemasan adalah perasaan subjektif dari ketegangan, ketakutan, kegugupan, dan kekhawatiran yang terkait dengan gairah sistem saraf (Spielberger, 1983). Pada konteks pendidikan, kecemasan studi adalah 
situasi khusus yang merujuk pada kondisi kecemasan yang dialami selama proses studi dan bisa menjadi gangguan kinerja akademik (Vitasari, dkk., 2010). Berdasarkan beberapa penelitian terdahulu, jenis kecemasan yang dapat terjadi pada ruang lingkup pendidikan antara lain adalah kecemasan tes, kecemasan statistis, kecemasan sosial, dan lain sebagainya.

Jurnal ini bertujuan untuk memberikan gambaran umum mengenai kecemasan mahasiswa dan hubungannya dengan pretasi akademik pada mahasiswa di perguruan tinggi. Gambaran umum mengenai kecemasan mahasiswa dan hubungannya dengan prestasi akademik bermanfaat untuk menentukan intervensi yang tepat diberikan bagi mahasiswa yang mengalami kecemasan. Pemberian intervensi yang tepat diharapkan dapat berdampak pada meningkatnya prestasi akademik mahasiswa. Selain itu, gambaran umum mengenai hubungan kecemasan dengan prestasi akademik juga dapat bermanfaat untuk menentukan tindakan preventif guna menurunkan tingkat kecemasan pada mahasiswa.

\section{METODE}

Tinjauan sistematik ini menggunakan teknik compare dan contrast. Compare merupakan teknik tinjauan sistematik yang isinya berupaya mencari kesamaan pada kasus yang diteliri. Sementara contrast merupakan teknik tinjauan sistematik yang isinya berupaya mencari perbedaan pada kasus yang diteliti.

Penelitian ini didasarkan pada beberapa literatur. Pencarian literatur dilakukan secara online melalui tiga basis pencarian data yaitu adalah Education Resources Information Center (ERIC) dengan alamat URL: ERIC.edu.gove; Science Direct dengan alamat URL: sciencedirect.com; dan ProQuest dengan alamat URL: proquest.com. Pencarian literatur dilakukan selama tiga minggu mulai dari 2-22 September 2019. Kata kunci yang digunakan dalam pencarian jurnal adalah "anxiety" and "academic achievement" and ("college student" or "university student").

Pemilihan literatur didasarkan pada kriteria inklusi dan eksklusi. Kriteria inklusi pemilihan literatur dalam penelitian ini yaitu: 1) Membahas mengenai prestasi akademik; 2) Membahas mengenai kecemasan; dan 3) Konteks penelitian pada mahasiswa. Sementara kriteria eksklusi pemilihan literatur dalam penelitian ini yaitu: 1) Penelitian yang dilakukan dalam rentang waktu melebihi dari 10 tahun terakhir (sebelum 2009); 2) Bukan berupakan artikel penelitian; dan 3) Belum melalui proses peer-reviewed.

Selain menentukan kriteria inklusi dan eksklusi, pemilihan literatur juga didasarkan pada proses penyeleksian abstrak. Berdasarkan keriteria dan seluruh proses yang telah dijelakan sebelumnya, penelitian ini memilih 5 literatur untuk diulas. Terdapat 2 artikel yang diperoleh dari science direct, 2 artikel yang diperoleh dari ProQuest, dan 1 artikel yang diperoleh dari ERIC.

\section{HASIL DAN PEMBAHASAN}

Sebelum melakukan sintesis literature, peneliti terlebih dahulu menganalisis kualitas jurnal yang akan 
digunakan di dalam penelitian ini. Setelah menyeleksi jurnal berdasarkan kriteria eksklusi dan inklusi, selanjutnya peneliti menganalisis kualitas jurnal menggunakan Quality Assessment Quantitative Papers yang diciptakan oleh Cummings \& Estabrooks. Hasil analisis kualitas literatur terdapat pada tabel 1 dibawah ini.

Tabel 1. Hasil Analisis Kualitas Literatur

\begin{tabular}{|c|c|c|c|c|c|c|c|}
\hline \multirow[b]{2}{*}{ Design: } & \multicolumn{5}{|c|}{ Jurnal } & \multicolumn{2}{|c|}{ Total } \\
\hline & 1 & 2 & 3 & 4 & 5 & Yes & No \\
\hline Prospective studies & 1 & 1 & 1 & 1 & 1 & 5 & 0 \\
\hline $\begin{array}{l}\text { Used probability } \\
\text { sampling }\end{array}$ & 1 & 1 & 1 & 1 & 1 & 5 & 0 \\
\hline \multicolumn{8}{|l|}{ Sample: } \\
\hline $\begin{array}{l}\text { Appropriate/justifi } \\
\text { ed sample size }\end{array}$ & 1 & 1 & 1 & 1 & 1 & 5 & 0 \\
\hline $\begin{array}{l}\text { Sample drawn } \\
\text { from more than } \\
\text { one site }\end{array}$ & 0 & 0 & 1 & 1 & 1 & 3 & 2 \\
\hline $\begin{array}{l}\text { Anonymity } \\
\text { protected }\end{array}$ & 1 & 1 & 1 & 1 & 1 & 5 & 0 \\
\hline $\begin{array}{l}\text { Response } \\
\text { rate }>60 \%\end{array}$ & 1 & 1 & 1 & 1 & 1 & 5 & 0 \\
\hline \multicolumn{8}{|l|}{ Measurement: } \\
\hline Reliable & 1 & 1 & 1 & 1 & 1 & 5 & 0 \\
\hline $\begin{array}{l}\text { Restructuring was } \\
\text { of sufficient } \\
\text { magnitude to be } \\
\text { measured }\end{array}$ & 1 & 1 & 1 & 1 & 1 & 5 & 0 \\
\hline $\begin{array}{l}\text { Effects (outcomes) } \\
\text { were measured } \\
\text { rather than self- } \\
\text { reported* }\end{array}$ & 0 & 1 & 0 & 0 & 1 & 2 & 3 \\
\hline $\begin{array}{l}\text { Internal } \\
\text { consistency } \geq .70 \\
\text { when scale used }\end{array}$ & 0 & 1 & 1 & 1 & 1 & 4 & 1 \\
\hline $\begin{array}{l}\text { Theoretical } \\
\text { model/framework } \\
\text { used }\end{array}$ & 1 & 1 & 1 & 1 & 1 & 5 & 0 \\
\hline \multicolumn{8}{|l|}{ Statistical Analysis: } \\
\hline $\begin{array}{l}\text { Correlations } \\
\text { analysed when } \\
\text { multiple effects } \\
\text { studied }\end{array}$ & 0 & 0 & 1 & 1 & 1 & 3 & 2 \\
\hline $\begin{array}{l}\text { Management of } \\
\text { outliers addressed }\end{array}$ & 0 & 0 & 1 & 0 & 0 & 1 & 4 \\
\hline TOTAL & 8 & 11 & 12 & 11 & 13 & & \\
\hline
\end{tabular}

Sebuah artikel literature

dikatakan memiliki kualitas sedang apabila memperoleh skor 5-9 dan memiliki nilai yang baik apabila memperoleh skor 10-14 (Cummings, G.,
\& Estabrooks, 2003). Berdasarkan analisis yang telah dilakukan terhadap kelima literatur yang digunakan dalam penelitian ini, terdapat 1 literatur yang memiliki kualitas sedang dan 4 literatur yang memiliki kualitas baik.

Setelah melakukan pencarian dan proses penyeleksian, terdapat 5 literatur yang dipilih untuk digunakan dalam penelitian ini. Literatur-literatur tersebut terdapat pada tabel 2 dibawah ini. 
Tabel 2. Rangkuman Hasil Tinjauan Literatur

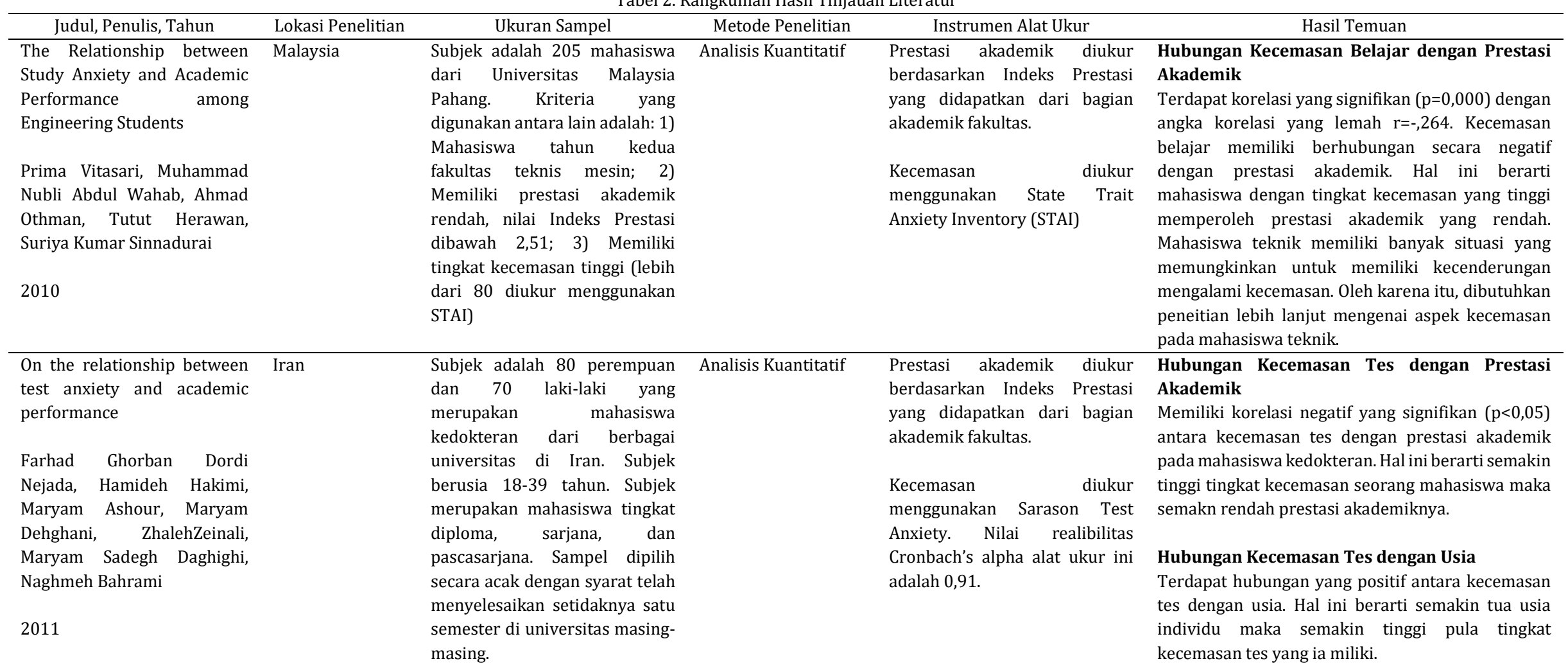

\section{Hubungan Kecemasan Tes dengan Tingkat} Semester

Tidak terdapat hubungan yang signifikan antara kecemasan tes dengan tingkat semester seorang mahasiswa

Hubungan Kecemasan Tes dengan Tingkat Pendidikan

Mahasiswa dengan tingkat pendidikan yang lebih rendah mengalami tingkat kecemasan tes yang lebih tinggi 


\section{Faktor Kecemasan Tes}

Kecemasan tes dapat diakibatkan oleh beragam faktor. Antara lain adalah silabus yang rumit, aitem tes, frekuensi tes, budaya pendidikan, dan lain sebagainya. Faktor-faktor ini belum tentu menjadi faktor penentu kecemasan tes pada lingkungan pendidikan yang bereda. Sehingga masing-masing lingkungan pendidikan mungkin memiliki gambaran kecemasan dan faktor kecemasan yang khas pada masing-masing lingkungan.

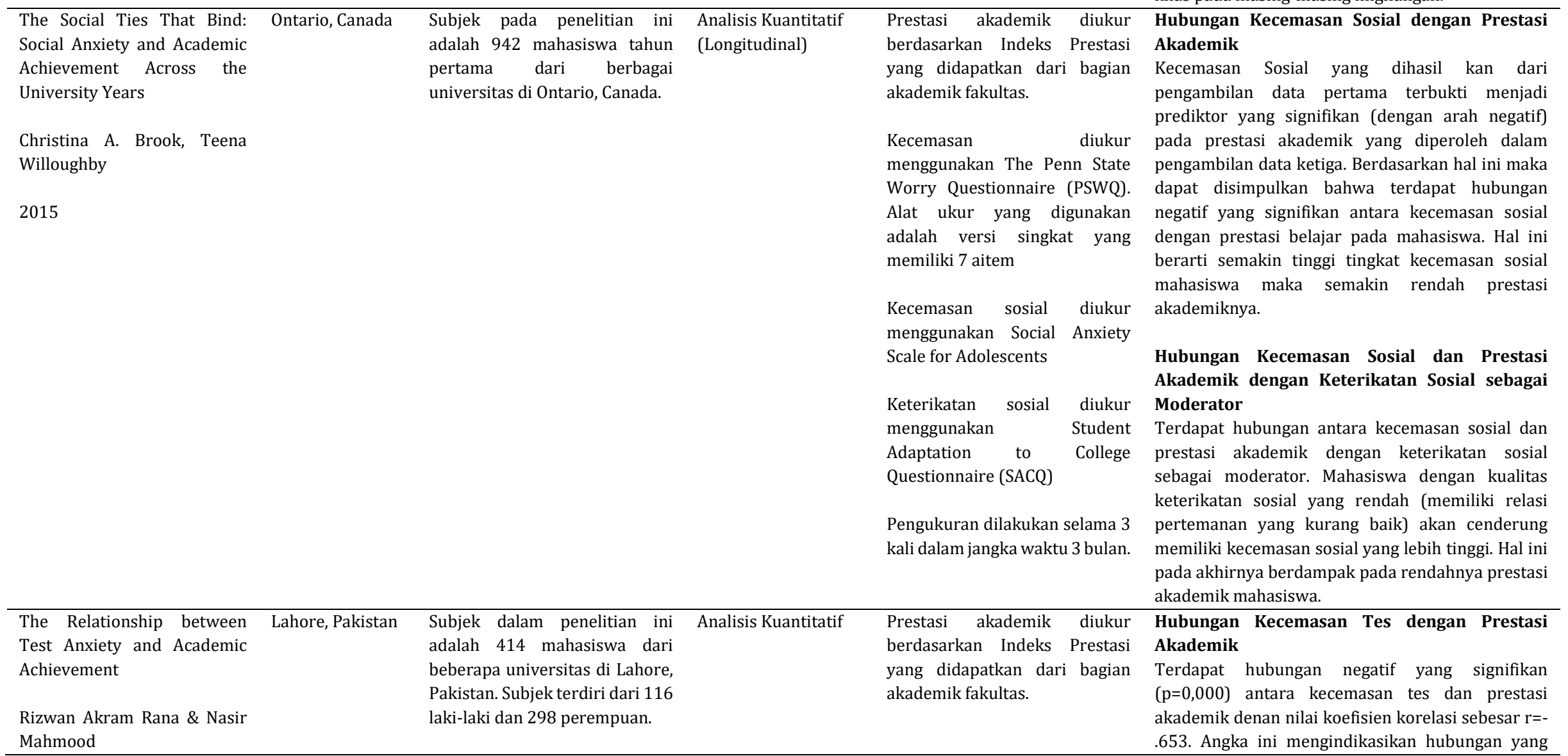

Kecemasan Sosial dengan Prestasi Akademik 
2010
Kecemasan tes

menggunakan

Inventory (TAI) diukur Anxiety

ak

akademik. Kecemasan tes memberi sumbangan negatif sebanyak lebih dari $65 \%$ terhadap prestasi akademik. Hal ini berarti semakin tinggi kecemasan tes seorang mahasiswa maka semakin rendah prestasi akademiknya.

\section{Pengaruh Kecemasan Tes terhadap Prestasi} Akademik

Kecemasan tes terbukti mempengaruhi prestasi akademik secara signifikan $(\mathrm{p}=0,000)$.

Faktor Kognitif dan Faktor Afektif pada Kecemasan Tes

Penelitian ini memperoleh hasil bahwa faktor kognitif memiliki hubungan dan pengaruh yang lebih besar terhadap kecemasan tes. Pada penelitian ini terbukti bahwa jika tes yang diadakan memiliki sifat yang lebih rigid dan terstruktur, maka akan meningkatkan kecemasan mahasiswa. Selain itu, faktor kognitif yang terkait dengan bagaimana mahasiswa mempersepsikan hasil dan tujuan juga berhubungan dengan kecemasan. Semakin mahasiswa memikirkan tentang hasil yang telah diekspektasikan, maka semakin tinggi pula kecemasan tesnya.

Meskipun demikian, faktor afektif juga tetap dapat mempengaruhi kecemasan tes pada mahasiswa. Perasaan yang mereka rasakan sebelum tes berlangsung, akan meningkatkan kecemasan mereka. Hal ini juga dapat terjadi pada setting lain diluar setting tes pada ruang lingkup pendidikan.

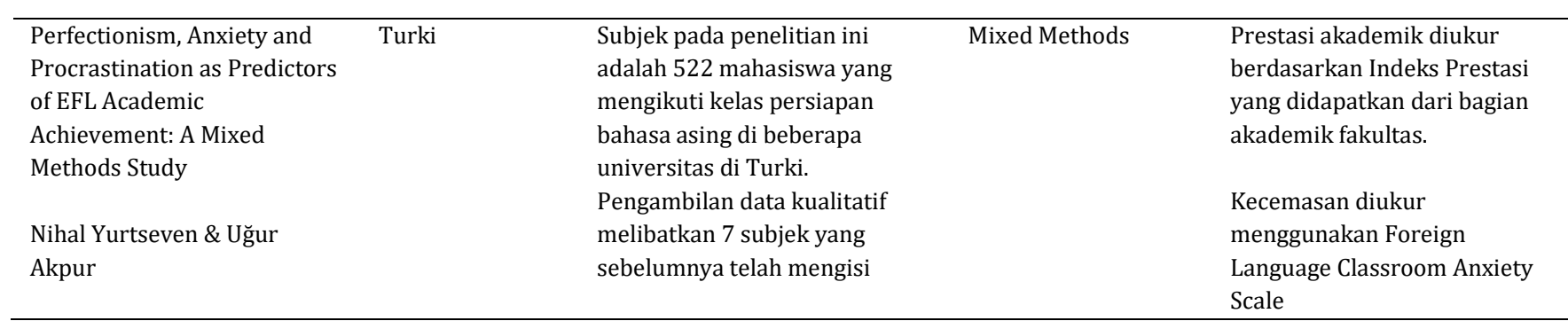

Hubungan Kecemasan dengan Prestasi

\section{Akademik}

Terdapat hubungan negatif yang signifikan

$(p<0,01)$ antara kecemasan dan prestasi akademik.

Nilai koefisien korelasi antara kedua variabel ini

adalah $\mathrm{r}=-, 72$ yang berarti hubungan kedua

variabel ini merupakan hubungan yang kuat. 
Dhian Kusumastuti, Kecemasan Dan Prestasi Akademik Pada Mahasiswa

2018 kuesioner yang bersedia untuk

diwawancarai
Perfeksionisme diukur

menggunakan Frost

Multidimensional Perfectionism

Scale

Perilaku prokrastinasi diuku

menggunakan Aitken Academic

Procrastination Inventory

Data kualitatif diperoleh

menggunakan wawancara grup

Peneliti menggunakan setting

lingkungan natural tanpa

manipulasi. Wawancara

berlangsung selama kurang

lebih 45 menit.
Kecemasan sebagai Prediktor Prestasi

Akademik

Penelitian ini membuktikan bahwa kecemasan

merupakan prediktor prestasi akademik $(\mathrm{p}<0,01)$

Faktor Prediktor terkuat dari Prestasi

Akademik

Berdasarkan data dari penelitian ini, kecemasan

merupakan variabel yang paling kuat yang dapat

memprediksi capaian prestasi akademik

mahasiswa. Tiga katagori kecemasan yang dialami

mahasiswa di kelas bahasa asing adalah ketakutan

membuat kesalahan, tekanan dari rekan, dan

antusiasme yang berlebihan

Faktor yang meningkatkan kecemasan

Terdapat dua faktor yang dapat meningkatkan

tingkat kecemasan pada mahasiswa yaitu faktor

intrapersonal (ketakutan membuat kesalahan,

kurang keberanian, kurang efikasi diri) dan faktor

interpersonal (tekanan dari rekan dan sikap

pengajar) 
Berdasarkan tinjauan sistematik yang telah dilakukan, kesamaan yang ditemukan pada seluruh jurnal yang digunakan dalam penelitian ini adalah bahwa kecemasan memiliki hubungan negatif dengan prestasi akademik mahasiswa. Hal ini berarti semakin tinggi kecemasan yang dialami oleh mahasiswa maka akan semakin rendah tingkat prestasi akademik mereka. Meskipun demikian, kecemasan yang dialami oleh para mahasiswa tidak hanya kecemasan dalam bentuk umum akan tetapi juga kecemasan dalam hal khusus tertentu.

Berdasarkan lima jurnal yang digunakan dalam penelitian ini, perbedaan yang ditemukan adalah bahwa terdapat berbagai jenis kecemasan yang dialami oleh para mahasiswa. Jenis-jenis kecemasan tersebut antara lain adalah kecemasan studi, kecemasan tes, serta kecemasan sosial. Kecemasan studi adalah situasi spesifik yang merujuk pada keadaan cemas yang dialami selama proses studi dan dapat mengganggu performa akademik (Vitasari, dkk., 2010). Secara lebih spesifik, kecemasan tes adalah salah satu jenis kecemasan yang terjadi saat seorang individu sedang melakukan tes atau sedang menjalani proses evaluasi oleh pelaksana tes (DordiNejad, dkk., 2011). Sementara kecemasan sosial adalah kecemasan yang terjadi pada situasi sosial (Brook, C., \& Wiloughby, 2015).

Penelitian yang dilakukan oleh Vitasari, dkk. (2010) terhadap 205 mahasiswa dari fakultas teknik mesin di Universitas Malaysia Pahang membuktikan bahwa kecemasan studi secara signifikan memiliki hubungan negatif degan prestasi akademik mahasiswa. Penelitian lain yang dilakukan terhadap mahasiswa kedokteran menunjukkan jenis kecemasan yang berbeda. DordiNejad, dkk. (2011) dalam penelitian mereka membuktikan bahwa kecemasan tes memiliki hubungan negatif yang signifikan dengan prestasi akademik. Sejalan dengan hal ini, penelitian yang dilakukan oleh Rana \& Mahmood (2010) terhadap 414 mahasiswa dari beberapa fakultas di Lahore juga menunjukkan bahwa kecemasan tes memiliki hubungan negatif yang signifikan dengan prestasi akademik mahasiswa. Penelitian lain yang dilakukan terhadap mahasiswa tahun pertama, jenis kecemasan yang memiliki hubungan dengan prestasi akademik adalah kecemasan sosial. Berdasarkan penelitian yang dilakukan oleh Brook, C., \& Wiloughby (2015) membuktikan bahwa kecemasan sosial memiliki hubungan negatif yang signifikan terhadap prestasi akademik mahasiswa. Sementara pada mahasiswa kelas asing, terdapat jenis kecemasan yang khas yaitu kecemasan kelas bahasa asing. Yurtseven \& Akpur (2018) dalam penelitiannya membuktikan bahwa kecemasan kelas bahasa asing memiliki hubungan negatif yang signifikan dengan prestasi akademik. Selain itu, kecemasan kelas bahasa asing juga merupakan prediktor terkuat terhadap prestasi akademik mahasiswa dibandingkan dengan sifat perfeksionisme dan prokrastinasi pada mahasiswa di kelas bahasa asing.

Perbedaan jenis kecemasan pada mahasiswa dapat disebabkan oleh ciri khas masing - masing konteks 
pendidikan. Pada mahasiswa fakultas teknik mesin, kecemasan yang kerap terjadi adalah kecemasan studi secara umum. Kecemasan studi yang dimaksud dalam penelitian ini adalah kecemasan yang secara umum muncul dalam ruang lingkup studi tidak spesifik pada satu situasi tertentu seperti situasi belajar di kelas, belajar berkelompok, maupun ujian. Vitasari,dkk. (2010) dalam penelitiannya menyatakan bahwa terdapat banyak situasi yang memungkinkan mahasiswa teknik mengalami kecemasan. Padatnya kegiatan, banyaknya tugas yang harus dikerjakan, dan kerumitan ujian yang harus dijalani dapat menjadi faktorfaktor yang menyebabkan para mahasiswa teknik mengalami kecemasan studi secara umum tidak hanya spesifik pada satu situasi tertentu. Kecemasan yang tidak dapat mereka tanggulangi ini akhirnya berdampak pada prestasi akademik mereka yang rendah (Vitasari, dkk., 2010).

Mahasiswa dalam menempuh pendidikan tentu tidak lepas dari tes maupun ujian. Pada beberapa fakultas yang kerap kali mengadakan tes untuk mengevaluasi hasil belajar mahasiswa, kerap menimbulkan kecemasan yang khas pada beberapa mahasiswanya. Kecemasan tersebut biasa disebut dengan kecemasan tes. Berdasarkan penelitian yang dilakukan oleh Rana \& Mahmood (2010) terbukti bahwa mahasiswa kerap kali memikirkan tentang hasil yang akan dicapai setelah tes atau ujian selesai dilakukan. Pikiranpikiran mengenai hasil tes inilah yang kerap kali membuat para mahasiswa menjadi mengalam kecemasan tes. Selain itu, Rana \& Mahmood (2010) juga mengatakan bahwa semakin rigid tes yang diadakan, maka akan semakin tinggi pula tingkat kecemasan tes yang dialami para mahasiswa. Kecemasan tes ini juga kerap kali dialami oleh para mahasiswa kedokteran. Selama menempuh pendidikan, mahasiswa kedokteran kerap kali dihadapkan pada berbagai tes dan ujian. Kondisi ini membuat mereka rentan mengalami kecemasan tes. Pada mahasiswa kedokteran, semakin tinggi tingkat pendidikan seseorang maka akan semakin rendah kecemasan tes yang mereka alami (DordiNejad, dkk., 2011). Hal ini dapat terjadi karena mereka sudah mulai terbiasa dengan situasi tes yang harus mereka hadapi. Pernyataan ini menyatakan bahwa salah satu faktor kecemasan tes adalah seberapa sering individu menghadapi situasi tes (frekuensi tes). Berdasarkan penelitian yang dilakukan oleh Rana \& Mahmood (2010) dan DordiNejad, dkk. (2011) ini terbukti bahwa tingkat kecemasan tes yang tinggi memiliki hubungan dengan prestasi akademik yang rendah.

Pada mahasiswa tahun pertama, jenis kecemasan yang kerap dialami adalah kecemasan sosial. Salah satu tantangan yang harus dihadapi oleh mahasiswa tahun pertama adalah tantangan untuk dapat beradaptasi di sebuah lingkungan baru. Menghadapi hal ini, mahasiswa tahun pertama memiliki kebutuhan akan adanya keterikatan sosial dengan lingkungan tempat mereka berada. Mereka memiliki harapan untuk dapat menciptakan impresi yang baik didepan orang-orang disekitarnya (Schlenker \& Leary, 1982). Harapan mereka akan impresi baik inilah yang pada akhirnya membuat mereka 
memiliki kecemasan sosial. Brook \& Wiloughby (2015) dalam penelitiannya membuktikan bahwa seseorang dengan keterikatan sosial serta kualitas pertemanan yang buruk memiliki tingkat kecemasan sosial yang tinggi. Pada akhirnya hal ini berdampak pada rendah nya prestasi akademik yang mereka miliki.

Secara khusus pada kelas bahasa asing, mahasiswa kerap mengalami kecemasan yang khas. Kecemasan ini oleh Aydin (1999) disebut sebagai kecemasan kelas bahasa asing (foreign language classroom anxiety). Pada kelas bahasa asing, mahasiswa terlibat dalam situasi yang mengharuskan mereka berbicara didepan mahasiswa lain dengan menggunakan bahasa asing. Pada situasi ini kemampuan berbahasa mereka disaksikan dan diperhatikan oleh orang-orang yang berada dalam kelas tersebut. Situasi ini kerap membuat mereka merasa cemas. Berdasarkan penuturan salah satu subjek dalam penelitian yang dilakukan oleh Yurtseven \& Akpur (2018), kecemasan yang mereka alami antara lain adalah takut membuat kesalahan. Mereka memiliki kekhawatiran akan adanya ledekan atau cemoohan ketika mereka membuat salah. Tak hanya itu, mahasiswa di kelas bahasa asing kerap kali ingin menunjukkan kemampuannya di depan teman-temannya di kelas. Antusiasme mereka yang tinggi ini juga kerap meningkatkan kecemasan mereka. Tingkat kecemasan yang tinggi pada mahasiswa kelas bahasa asing ini pada akhirnya berdampak pada prestasi akademik mereka yang rendah.

Pemaparan

diatas

menggambarkan bahwa mahasiswa kerap mengalami kecemasan selama masa studi nya. Akan tetapi, terdapat berbagai jenis kecemasan berbeda yang mungkin dialami oleh mahasiswa. Perbedaan budaya pendidikan, bobot tugas, jenis ujian, kurikulum, dan lain sebagainya dapat menyebabkan perbedaan jenis kecemasan pada mahasiswa.

\section{SIMPULAN}

Berdasarkan tinjauan sistematik tehadap 5 jurnal yang digunakan pada penelitian ini, maka dapat disimpulkan bahwa kecemasan memiliki hubungan dengan arah negatif dengan prestasi akademik pada mahasiswa. Meskipun demikian, terdapat beragam jenis kecemasan yang dapat dialami oleh mahasiswa. Perbedaan jenis kecemasan yang dialami oleh mahasiswa ini dapat disebabkan oleh perbedaan ciri khas pada masing-masing konteks pendidikan. Penelitian selanjutnya disarankan untuk lebih memfokuskan pada satu tujuan. Penelitian ini berusaha untuk mengungkap gambaran kecemasan mahasiswa dan hubungan kecemasan dengan prestasi akademik. Keberadaan dua tujuan dalam satu penelitian ini membuat peneliti sulit untuk memfokuskan diskusi penelitian pada satu hal antara gambaran kecemasan dengan hubungan kecemasan dan prestasi akademik pada mahasiswa. Penelitian selanjutnya dengan topik serupa diharapkan bisa membahas secara lebih dalam dan menyeluruh mengenai gambaran kecemasan pada mahasiswa maupun dinamika hubungan kecemasan dan prestasi akademik pada mahasiswa. 


\section{DAFTAR PUSTAKA}

Azizy, I. V., Mustikawati, I. F., \& Ulfa, M. (2019). Hubungan Antara Tipe Kepribadian Dan Tingkat Kecemasan Dengan Prestasi Akademik Mahasiswa Program Studi Pendidikan Dokter Universitas Muhammadiyah Purwokerto. Jurnal Saintika Media, 78-83.

Aydin, B. (1999). A Study of Source Foreign Language Classroom Anxiety in Speaking and Writing Classes. Disertasi.

Brook, C., \& Wiloughby, T. (2015). The Social Ties That Bind: Social Anxiety and Academic Achievement Across the University Years. J Youth Adolescence, 1139-1152.

Cummings, G., \& Estabrooks, C. (2003). The Effects of Hospital Restructuring That Included Layoffs on Individual Nurses Who Remained Employed: A systematic Re- view of Impact. International Journal of Sociology and Social Policy, 8-53.

DordiNejad, F. G., Hakimi, H., Ashouri, M., Dehghani, M., Zeinali, Z., Daghighi, M. S., \& Bahrami, N. (2011). On The Relationship between Test Anxiety and Academic Performance. Precedia Social and Behavioral Science, 3774-3778.

Khalaila, R. (2014). The relationship between academic self-concept, intrinsic motivation, test anxiety, and academic achievement among nursing students: Mediating and moderating effects. Nurse Education Today, 1-7.

Marthoenis, Meutia, I., Fathiariani, L., \& Sofyan, H. (2018). Prevalence of Depression and Anxiety among College Students Living in A Disaster-prone Region. Alexandria Journal of Medicine, 1-4.

McCraty, R. (2007). When Anxiety Causes Your Brain to Jam, use Your Heart. Institute of Heart Math.

Rana, R. A., \& Mahmood, N. (2010). The Relationship between Test Anxiety and Academic Achievement. Bulletin of Education and Research, 63-74.

Schlenker, B., \& Leary, M. (1982). Social Anxiety and Self-Presentation: A Conceptualization and Model. Psychological Bulletin, 641-669.

Spielberger, C. D. (1983). State Trait Anxiety. Mind Garden Inc.

Thomas, C., Cassady, J., \& Heller, M. (2017). The Influence of Emotional Intelligence, Cognitive Test Anxiety, and Coping
Strategies on Undergraduate Academic Performance. Learning and Individual Differences, 40-48.

Vitasari, P., Wahab, M. N., Othman, A., Herawan, T., \& Sinnadurai, S. K. (2010). The Relationship between Study Anxiety and Academic Performance among Engineering Students. International Conference on Mathematics Education Research, 490-497.

Wahyudi, H. (2015). Analisis Faktor-Faktor yang Menyebabkan Prestasi Akademik Rendah pada Mahasiswa Non-Pendas di UPBJJ-UT Denpasar. Seminar Nasional Riset Inovatif III, 52-58.

Yurtseven, N., \& Akpur, U. (2018). Perfectionism, Anxiety and Procrastination as Predictors of EFL Academic Achievement: A Mixed Methods Study. Novitas-ROYAL (Research on Youth and Language), 96-115. 